\title{
EFFECTS OF BRACING OF HIGH-RISE BUILDINGS UPON THEIR STATIC AND DYNAMIC BEHAVIOR
}

\author{
Ol'ga IVÁNKOVÁ ${ }^{1,{ }^{*},}$, Dušan DROBNÝ ${ }^{1}$, Soňa MEDVECKÁ ${ }^{1}$ \\ ${ }^{1}$ Department of Structural Mechanics, Faculty of Civil Engineering, Slovak University of Technology, \\ Bratislava, Slovak Republic. \\ corresponding author:
}

\begin{abstract}
The paper describes effects of bracing of high-rise buildings upon their static and dynamic behaviour. In static and dynamic analyses, values of displacement for 4 different variants of stiffening elements distribution were calculated. The calculations were made for building both fixed into the ground and rested on elastic supports. The building was modelled as a 3D variant using Finite Element Method (FEM) in program Scia Engineer.
\end{abstract}

\author{
Keywords: \\ Computing model; \\ Dynamic behavior; \\ High-rise buildings; \\ Modal analysis; \\ Static behavior.
}

\section{Introduction}

Formerly, to obtain some knowledge of values of natural frequencies of high-rise buildings some substitute models like consoles, plane frames, etc. had to be used. Currently, computer technology allows one to create numerical spatial models that are very close to the real structure, as far as load, construction, material, and subsoil are concerned. The choice of a proper structural system and distribution of stiffening elements in the building, its wind and seismic load response remain an open question for designers.

\section{Basic parameters of the building}

Four spatial models of high-rise buildings with different distribution of stiffening walls were modelled using the program Scia Engineer, see Fig. 1. A multifunctional high-rise building with 22 floors and one underground floor was considered. The building varies in its horizontal crosssection and structural height of the floor. Bearing system is represented by concrete skeleton with stiffening cores and walls. Vertical bearing elements have various cross sections along the height of the building. Reinforced concrete walls are 200,250 or $300 \mathrm{~mm}$ thick. Particular columns of a square cross-section are $500,700,800$ and $850 \mathrm{~mm}$ wide. The building is founded on a reinforced concrete base plate, below the underground water level. Subsoil consists of gravel with medium to coarse-granularity, poorly grained. Under the gravel layer, there is an impermeable layer of compressible clays. The improvement of foundation soil using gravel pillars was considered. The maximum value of settlement is $51.4 \mathrm{~mm}$, from which the value of coefficient of compressibility 19.6 $\mathrm{MN} / \mathrm{m}^{3}$ was determined.

Building was designed in four variants, see Fig. 2. Variant 1 is the original one. In variant 2 stiffening wall in the $x$-direction was added. In variant 3 stiffening wall in the $y$-direction was added. Variant 4 is a combination of variants 2 and 3 . 


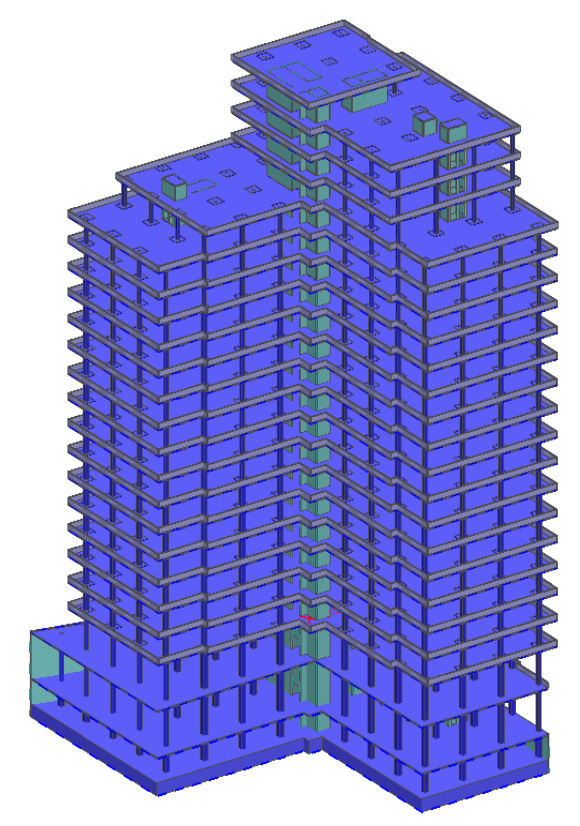

Fig. 1: Axonometry.
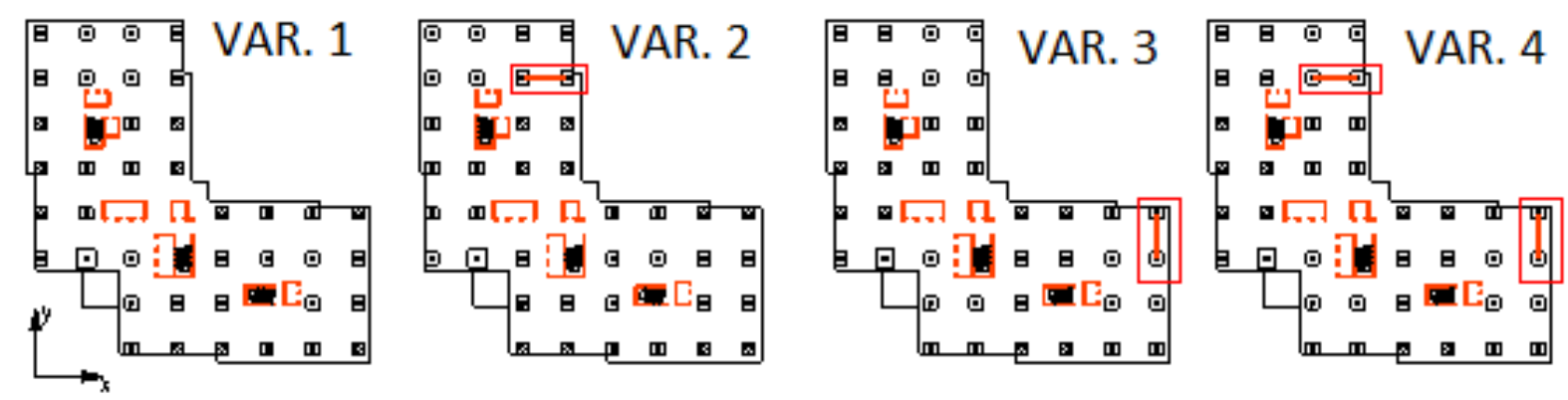

Fig. 2: Distribution of stiffening walls in the building.

\section{Input values}

For calculation of all the loads, valid standards EN 1991-1-1 (general loads), EN 1991-1-3 (snow load), EN 1991-1-4 (wind load), and EN 1998-1: Euro code 8 (earthquake resistance) were used. For purposes of static analysis, structures were loaded by most unfavourable combination of permanent, variable, and wind loads. For dynamic analysis the load was considered according to Eurocode. Structures were considered as fixed or rested on elastic support into the ground. The Winkler model had been used for modelling of subsoil. For static calculation the input value of coefficient of compressibility was taken $19.6 \mathrm{MN} / \mathrm{m}^{3}$. For dynamic calculations, where standards recommend to take higher value of coefficient of compressibility, the value was empirically determined as three times the rate $58.8 \mathrm{MN} / \mathrm{m}^{3}$. It takes into account the specific consolidation of the soil under dynamic loading. Dynamic analysis had been done for subsoil class B for value of seismic acceleration $0.35 \mathrm{~m} / \mathrm{s}^{2}$ and wind load with a basic wind speed $26 \mathrm{~m} / \mathrm{s}$. Loading of the building was considered in 4 directions, see Fig. 3. 


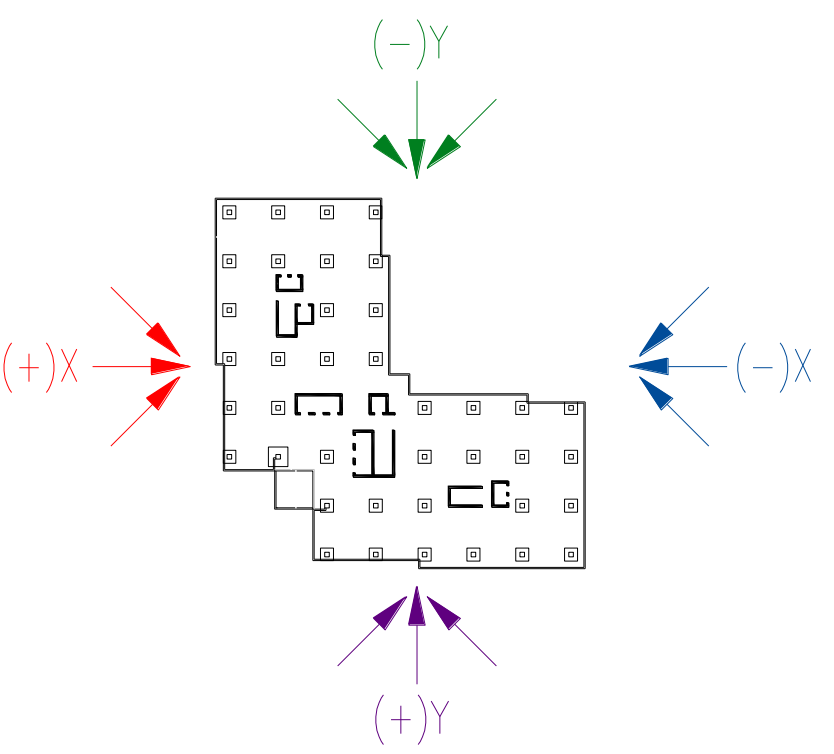

Fig. 3: Diagram of wind load.

\section{Static analysis}

For assessment of the most unfavourable static load combination with respect to standard EN, the maximum values of displacements in each direction have been compared. The displacements calculated for all variants are presented in the graphs, see Fig. 4. Maximum value of displacements are in direction of wind actions (-X), where in the first variant the maximum displacement is $58.5 \mathrm{~mm}$ in model fixed to ground and $84.5 \mathrm{~mm}$ in model with elastic supports. Graphic comparison of the maximum values of displacements of model fixed to ground and model with elastic supports for all variants is shown in Fig. 4.

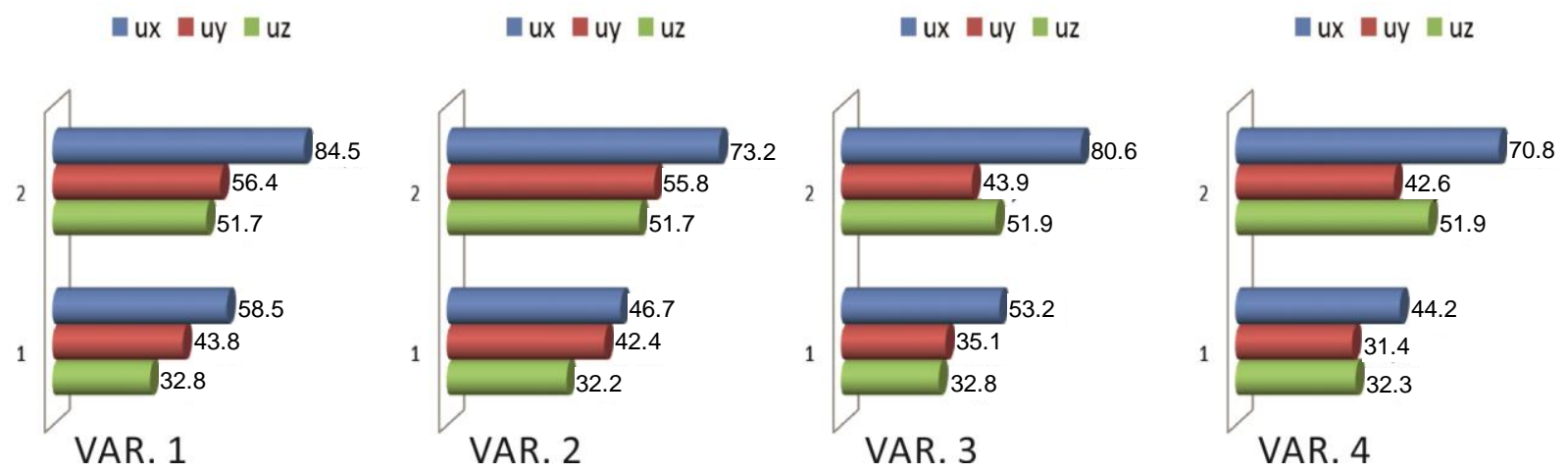

Fig. 4: Comparison of displacements, 1-fixed, 2-elastic support.

In dynamic analysis with the combination of static and dynamic loads (seismicity effects) were compared maximum values of displacement for the four alternatives with elastic support, where value of coefficient of compressibility was $58.8 \mathrm{MN} / \mathrm{m}^{3}$. For comparison of maximum values of the displacements in $X$ and $Y$ directions, see Fig. 5. Maximum value of displacement in direction $X$ is $55.0 \mathrm{~mm}$ in variants 2 and 4 and it is $51.7 \mathrm{~mm}$ in direction $Y$ in variant 2 . Increasing the stiffness of the building in the direction $X$ does not cause the reduction of displacements, which is the paradox. The reason is that the building varies in its horizontal cross-section. Another factor is the increase of the stiffness of the building, thereby increasing the natural frequencies. Due to this, in the spectral analysis the building is moved to areas of the graph with larger amplitudes of acceleration, thereby it is exposed to higher loads. 


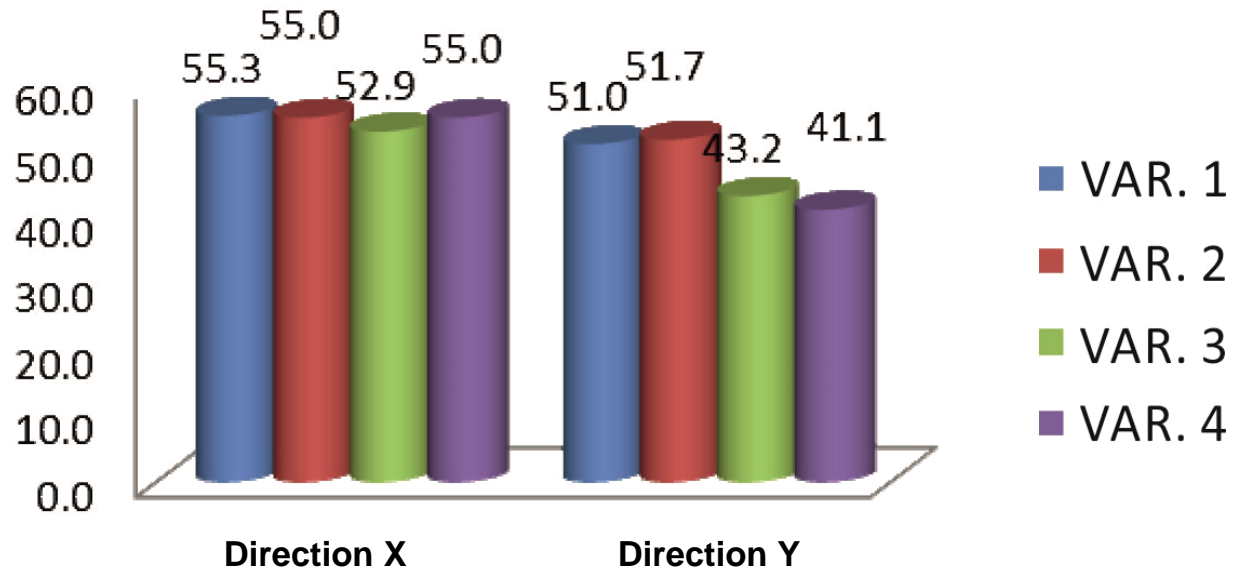

Fig. 5: The values of maximum displacements due to the seismic load.

\section{Modal analysis}

Other important factors are the values of the natural frequencies of the building, see Fig. 6 . In the calculation, first 300 natural modes were determined which originated in the frequency range from $0 \mathrm{~Hz}$ to $33 \mathrm{~Hz}$. Fig. 7 presents the comparison of values of natural frequencies of the first variant, both with fixed into the ground and rested elastic supports. Dependence is similar in other variants. Comparison of natural frequencies of the particular variants is shown in Fig. 8, where the value of coefficient of compressibility is $58.8 \mathrm{MN} / \mathrm{m}^{3}$.
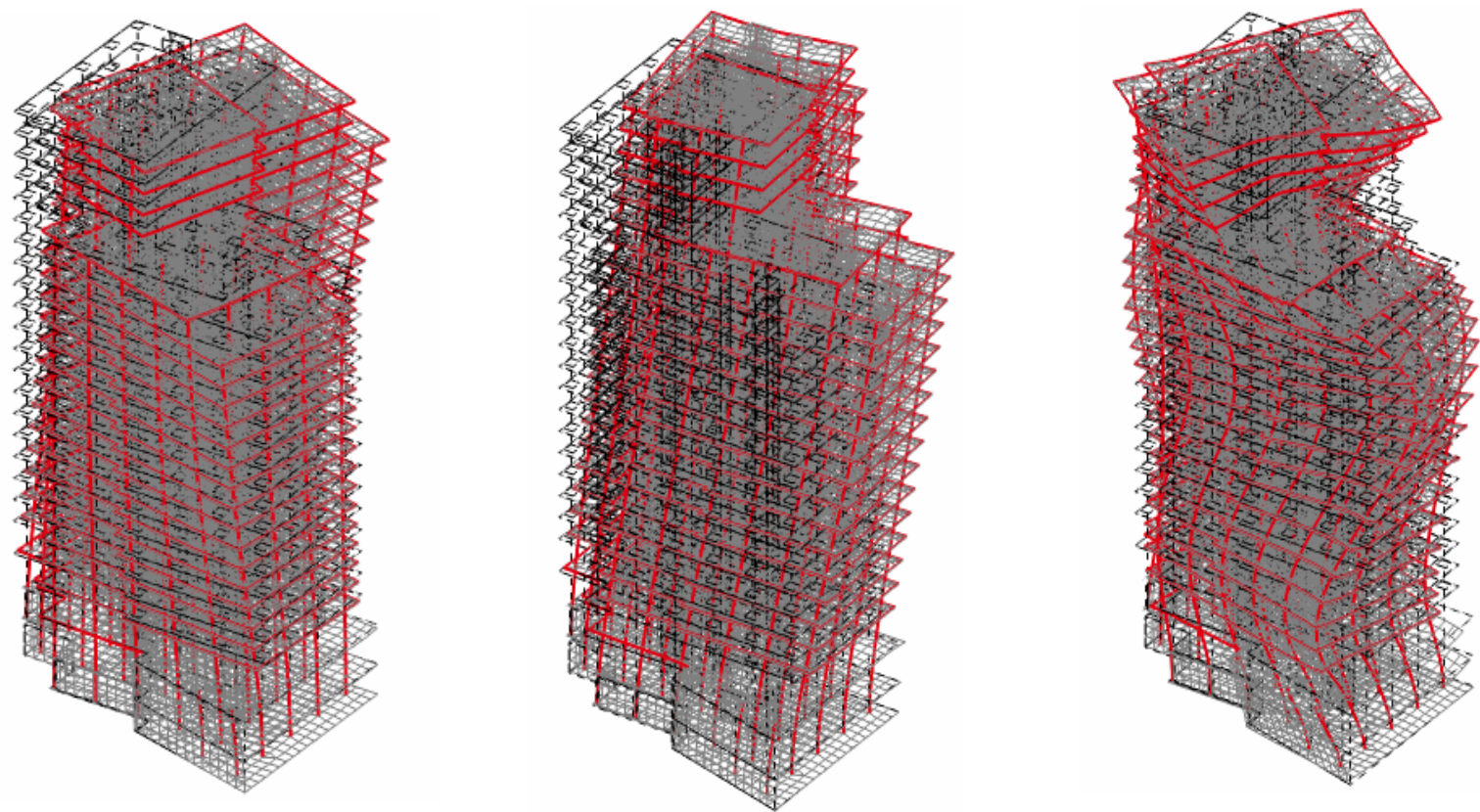

Fig. 6: Natural modes of variant $3\left(1^{\text {st }}, 2^{\text {nd }}\right.$, and $7^{\text {th }}$ natural mode $)$. 


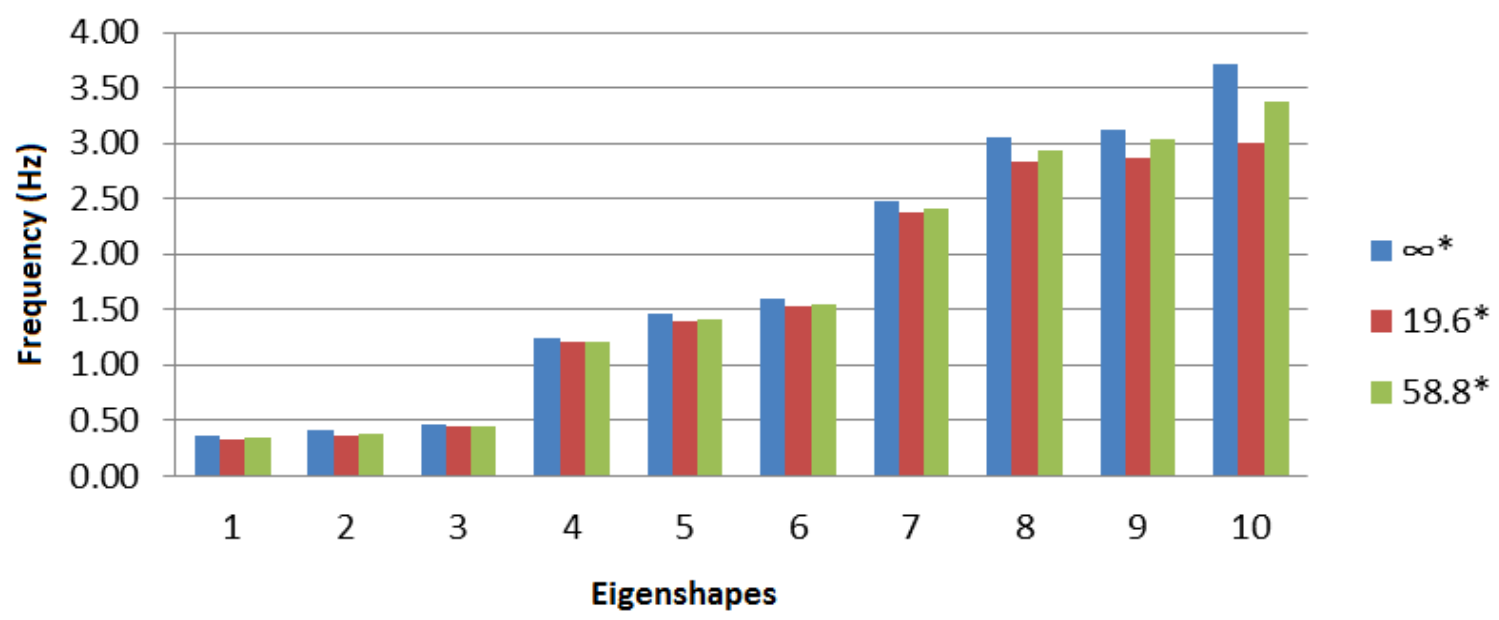

Fig. 7: Comparison of frequencies of natural modes in dependence on the subsoil for variant 1.

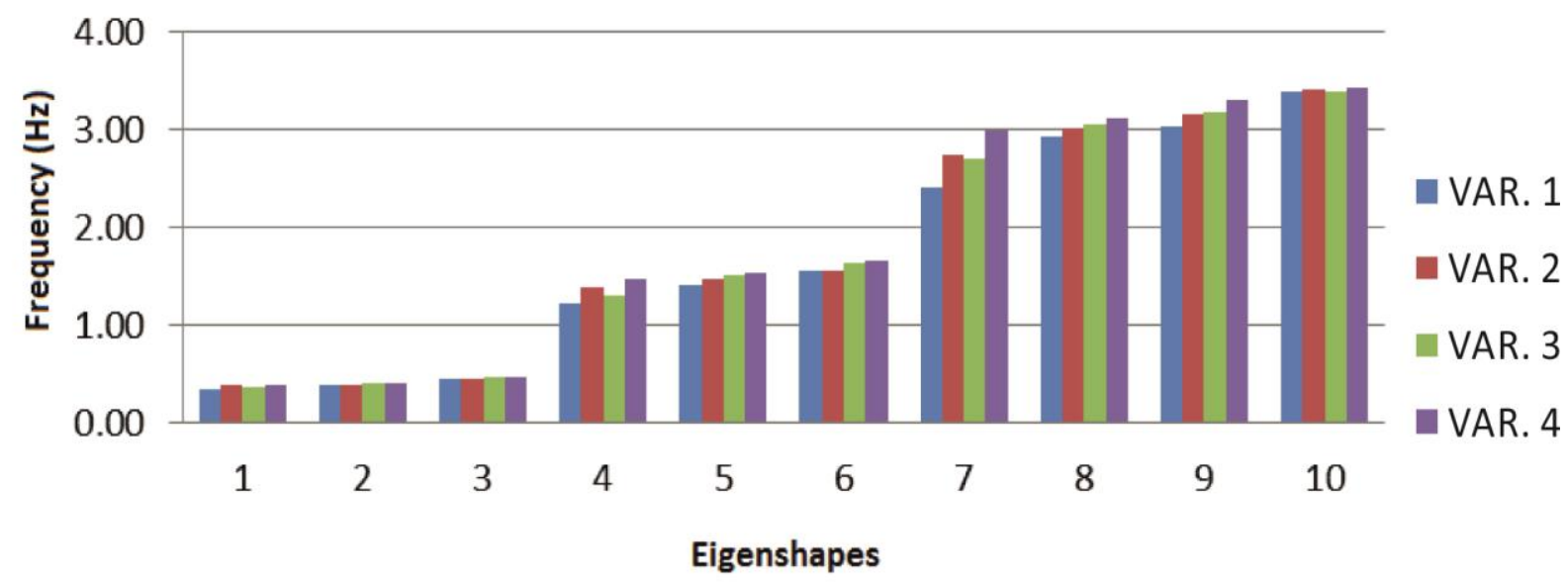

Fig. 8: Comparison of frequencies of natural modes in different variants.

\section{Conclusions}

In static calculation, after addition of stiffening elements (variant 4) the maximum value of displacement was reduced by $13.7 \mathrm{~mm}$ for building fixed into the ground and by $14.3 \mathrm{~mm}$ for building rested on elastic supports. It can be observed that the stiffening walls help to reduce displacements. This phenomenon depends on the type of soil.

In dynamic analysis, the difference between the values of displacements in variants 1 and 4 is negligible in the direction $\mathrm{X}$, however it is $13.9 \mathrm{~mm}$ in the direction $\mathrm{Y}$.

\section{Acknowledgement}

This paper was written with the support of Slovak Grant Agency VEGA. Registration number of the project is $01 / 1186 / 12$.

\section{References}

[1] JENDŽELOVSKÝ, N.: Modelovanie základových konštrukcií v MKP, STU, 92 s., ISBN 978-80227-30.

[2] SOKOL, M. - JUHÁSOVÁ, E. - BENKO, V.: Navrhovanie konštrukcií na seizmickú odolnost', Slovenská komora stavebných inžinierov, Bratislava, október, 2007. 
[3] MELCER, J.: Dynamické charakteristiky dial'ničného mosta pre horizontálny smer zat'aženia. Konferencija naukovo-techniczna. Aktualne problemy naukovo-badawcze budownictwa, Poland, Olsztyn-Lańsk, 2002, SPWE, Olsztyn, 2002, p. 481-488.

[4] MELCER, J. - KUCHÁROVÁ, D.: Static and dynamic behaviour of rail concrete slabs. Building Research Journal, Vol. 50, No. 2, 2002, p. 99-111.

[5] IVÁNKOVÁ, O. - JAVOREK, T.: Static and dynamic Analysis of the highrise Building Comparison of computing Results obtained using various software Systems. International Conference VSU'2005, Sofia 2005, pp. 108-111.

[6] KRÁLIK, J. - JAVOREK, T.: Numerical analysis of steel structure bracing system with linear and nonlinear characteristics. Proc. 8th Ansys Users' Meeting, SVS Brno, Lednice na Morave, sept. 2000. 